\title{
Neoliberalism and public library policy in Ireland, 1998-20 I I: From the first government policy document to the first general election after the Great Recession
}

International Federation of

Library Associations and Institutions $1-17$

(C) The Author(s) 2021

Article reuse guidelines: sagepub.com/journals-permissions DOI: 10.1 177/0340035220983354 journals.sagepub.com/home/ifl (S)AGE

\author{
Maureen Garvey (D) \\ Department of the Library, College of Staten Island, USA
}

\begin{abstract}
This article discusses the influence of neoliberal ideology on public libraries in Ireland, from the first government policy document published in 1998 to the first election after the recession in 20II. The context of the rise in importance of the idea of information and the parallel acceptance of the principles of the free market for providing public services are examined. The Irish government policy documents from the period are analyzed. A critical awareness of these changes is needed in the library and information science field to recognize and oppose policies that are detrimental to the public provision of a library service.
\end{abstract}

\section{Keywords}

Public library policy, Ireland, neoliberalism, public sphere

\section{Introduction}

In the next few days yet another article will be planted in one of our more conservatively inclined newspapers sketching out a blueprint for a radical restructuring of the National Health Service. You may glance at the byline, see the piece to be the product of a fringe right-wing think tank and dismiss it. Do not make that mistake. The article is simply the first shot in the latest campaign by the Adam Smith Institute, a body that has built up a startling track record for floating ideas which end up on the statute books. "We propose things which people regard as being on the edge of lunacy," says its president, Dr. Madsen Pirie. "The next thing you know, they're on the edge of policy." (Rusbridger, 1987)

Alan Rusbridger wrote this in The Guardian in December 1987. One of these proposals had been published the previous year as Ex Libris, the Adam Smith Institute's view on public libraries, written by Douglas Mason. It is an unrelenting attack on the public provision of a public library service:

The near total dependence on public funding is justified on the basis of a claimed contribution to the country's intellectual and economic development. Both claims are difficult to sustain. In reality, a substantial part of the public library system is now devoted to the supply of free fiction and other light reading, much of it of little or no literary merit to people who could afford to buy books but choose not to do so. (Mason, 1986: 5)

The aim of this article is to trace the movement of such ideas from "the edge of lunacy" to the heart of public policy in the subsequent decades, in the influence of neoliberal policy change on the public library service in Ireland. It takes as inspiration Greene and McMenemy's book chapter, "The emergence and impact of neoliberal ideology on UK public library policy, 1997-2010," published in 2012. This is original and much-needed work as there is an absence of such research on policy in Irish libraries. For example, a search of Google Scholar and of the author's library's discovery layer for the keywords 'Ireland

\section{Corresponding author:}

Maureen Garvey, Department of the Library, College of Staten Island, 2800 Victory Boulevard, Staten Island, New York, NY 10314, USA.

Email: maureen.garvey@csi.cuny.edu 
“public library" policy neoliberalism' returns no relevant results.

In the latter half of the 20th century, there was an indisputable and very well-documented ideological shift in the way polities of the Global North provided public services; these western liberal democracies moved from a model of adequate government funding, accepted by citizens, to inadequate public funds to be supplemented by the methods of private, profitmotivated business. This has continued apace in the 21 st century. This article takes as its natural starting point the first Irish government policy document for public libraries, Branching out, published in 1998. We continue through the beginning of the Great Recession in 2008, which had a tremendous impact on Ireland, to the 2011 general election - the first general election after the recession. This is the first part of a larger and longer-term project to continue this analysis from the Great Recession up to the present (and possibly also retrospectively before the issue of the first policy document). While the heart of this examination is the Irish government documents, an analysis of public policy in Ireland does not seem possible without reference to the UK (in relation to libraries, see Moran and Quinn, 2006). As with many areas, the UK has influenced Ireland to a large degree, and a comparison with its nearest neighbor (and former colonizer) proves instructive. We see that the trends evident in UK public libraries are present in Ireland during this period, though to a lesser extent. Those who want to defend the provision of a public library service must develop a critical awareness of these changes and develop strategies to combat them to retain current levels of service.

This change in the perception of the delivery of public services was part of a larger movement around the world. In the last approximately 50 years, we have lived through the move from the embedded liberalism of the postwar period as the dominant political ideology toward neoliberalism (market fundamentalism, the new public philosophy, or a myriad of other terms used by authors for these ideas). Embedded liberalism allowed for the public provision of certain services as necessary for a well-ordered, functioning society. The current movement of neoliberalism is defined by the primacy of the market as the best technique for delivering those services previously justified as requiring public provision due to their importance to society (for a more detailed explanation of the understanding of neoliberalism guiding our study, see Monbiot, 2016 and Harvey, 2005).

This primacy of the market is evident in the privatization of public services; public-private partnerships increasingly being used for large-scale infrastructure; arguments against the public provision of certain services; radical changes in those services remaining as public obligations; changes in work practices (an increase in temporary and part-time work to avoid provision of benefits to workers, a demand for more "flexibility" as in zero-hours contracts, outsourcing); corporate sponsorship of cultural events; and corporate encroachment on public space.

These changes have affected public libraries, in both the everyday practices of those working in them and their traditional role and defense in civil society (Chapman and Webster, 2006: 643). These changes are evident in a treatment of the patron or user as a customer, despite the non-transactional relationship; a focus on leisure and entertainment (as opposed to education and self-improvement); librarian neutrality as a virtue (manifesting in a prohibition on making judgements); the enthusiasm for the bookshop model being applied to public libraries; using volunteers for library work; the focus on quantitative evaluation to justify funding; the outsourcing of core library work; and the closing of libraries.

The erosion of libraries' traditional justification is due in part to marketization, which includes the commodification of information. In late capitalism, the market is encroaching on areas in which, some argue, it is undesirable. In capitalism's continuing need for expanding markets, new areas are appropriated. Manufacturing has left developed nations to be replaced by service occupations, and it is said that we are in an information society. Ultimately, there is a tension between viewing information as a commodity and upholding information access as a social and public good. Clearly, this will influence perceptions of the role of the library - though there have always been competing visions of the role of the library (see Black 2006: 22). This article intends to explore this tension and the effect of marketization of new areas - namely, the commodification of information - on libraries. How does the role of libraries sit with changing conceptions of democracy, public provision, and information? How has this been experienced by public libraries in Ireland?

First, we outline the parallel trends of the rise of the information society and what it means for libraries, and the concurrent movement to expand markets to include the commodification of information. Then, we incorporate scholarship on neoliberalism and public service. The penultimate section discusses the policy documents pertaining to public libraries issued by the Irish government in the relevant time period, and a brief case study of one library service. Our methodology in this section is a close reading and markup of the government-issued policy documents inspired by 
content analysis, looking for patterns, trends, and word frequencies. The concluding section argues for a deeper awareness within the profession of these changes to protect the public provision of the service, and a deeper engagement with democratic theory as a firm base for libraries' purpose and a necessary component of education for librarianship.

\section{Literature review}

\section{Effects of neoliberalism: the information society, marketization, quantitative evaluation, the public sphere, and public space}

With the shift from government-run public services to neoliberalism, the concept of "the information society" entered the western lexicon during a time when employment in so-called developed nations moved from manufacturing and industry to services or the information sector (Black and Hoare, 2006: 8; Chapman and Webster, 2006: 639). This concept of the information society and the idea that the West had entered into a distinct information age have "taken on an almost mythic status in contemporary discourse," according to Evans (2004: 5), but are "often used in a vague and ill-defined manner." And yet, "despite the imprecise nature of these terms they have been adopted by policymakers, practitioners and popular media to discuss a variety of key developments in economy and society" (Evans 2004: 5). Webster (1995) describes an explosion in the conceptual use of information in academia in Theories of the Information Society, some of which he locates in a plethora of business management publishing on the vital importance of information or knowledge to the economy. Government reports during the time period also trumpeted the importance of information/knowledge for a prosperous economy and society (e.g. Department of the Taoiseach, 2008a; see also Kirby, 2010: 153). Following this trend, libraries and library associations also began adopting the word "information" into their professional bodies and literature. Some departments and degrees moved from issuing a Master's in Library Science to a Master's in Library and Information Science, sometimes removing the word "library" altogether (the iSchool trend), in an effort to attract prospective students.

Two poles can be discerned around the concept in the literature: the utopian and the skeptical (Budd, 2008). Many who posit the existence of an information society are optimistic about the future, often to the point of breathlessness and "hegemonic hype" (Pascal and Slouka, in Evans, 2004: 10). Indeed, there is such fervor around the new information society that those who critique it find they have to defend themselves against accusations of pessimism (Robins and Webster, 1999: 6). Perhaps the most influential overview of the information society is that of Webster (1995), who affirms our "informatisation of life" yet has "serious doubts about the validity of the notion of an "information society"' (29). He draws a distinction between "'information society' theorists, who announce the novelty of the present, and 'informatisation' thinkers, who recognise the force of the past weighing heavily on today's developments" (6). While Webster can see the information society as a helpful "heuristic device," he finds that those information theorists who focus on quantitative approaches without taking into account the quality of information have diminished its value (27). Indeed, Buschman (2003) refers to Roszak's observation "that the word itself has become a "godword" (88) - something that means "all good things to all people. Words that come to mean everything may finally mean nothing; yet their very emptiness may allow them to be filled with a mesmerizing glamour" (89). ${ }^{2}$ Webster (1995: 220) finds those theorists to be more elucidating whose methods might be called political economy, who attempt to tie theory to what is taking place in the real world, having an effect on people's lives.

Technological advancement was viewed by some as not only shaping our material world but also transforming our social organization. The information society that technology gave rise to "was seen as embodying an inherently progressive social structure which would set humanity on a continuous trajectory of advancement in both economic and social relations" (Evans, 2004: 7). This technological determinism and the then recent collapse of communism allowed us to come to the point of such self-belief that, infamously, Fukuyama's (1992) book title The End of History and the Last Man could mistakenly be viewed by some as descriptive. In counterpoint to these views, "invocations of the information society and its 'new economy' are generally ambivalent towards the plight of labour, even though changes in the character of work are frequently at the centre of the observed (or proposed) transformations" (May, 2002: 49). Furthermore, Evans (2004: 11) states: "from today's perspective the early information theorists can be considered somewhat naive and also patronising. Few of their predictions have come true for the majority of workers in the West."

It is obvious that libraries have a real relationship to information and knowledge. But this rhetoric surrounding the information society can be a red herring, obfuscating the real political economy, and not a firm ground to support a defense of libraries, where it is 
often invoked. Library advocates should be critically aware of this rhetoric and pay attention to what information is being defined as, who is doing the defining, who has control over information, and how it is safeguarded, disseminated, and made available (freely or for profit).

Considering that their rationale rests on providing free access (at the point of use) to information, it would make sense to assume that the rising prominence of the concept of the information society would be a boon for libraries. But the phenomenal growth of the information economy was not reflected in public library funding. In trying to explicate why this might be the case, Goulding highlights two views of information and technology that emerged among both governments and policymakers internationally:

On the one hand, information is seen as a social good, enhancing the social, political and cultural life of citizenry or, indeed, as a "fourth right of citizenship"... On the other hand, information is also seen as an important commodity and an essential keystone for the continued prosperity of national economies. (Goulding, 2001: 1)

As Goulding (2001: 1) asks: "how well do these two visions fit together? Do they contradict one another or can they, in fact, be complementary?" Libraries exist right at this fault line (Black and Hoare, 2006: 9, Black 2006a: 22-23). These are not questions that will be resolved simply. Librarianship should cultivate a continued vigilance against rhetoric that allows it to be diminished.

Technological innovations that allow for better monitoring of information activities have accelerated information commodification.

Through this process, information becomes an exchangeable private product not a public reusable good... The danger is that governments, supported by business and industry, will place a higher priority on the development of ICTs [information and communications technologies] to support economic productivity than on assisting social cohesion and progress. (Goulding, 2001: 2)

They will just hope for the trickle-down effect to populations that Evans (2004) defined as neoliberalism. Despite the anachronistic acronym, this view, written in 2001 before the advent of social media or smartphones, seems prophetic of our current situation.

A concomitant transformation during this period of focus on information has been the effect of neoliberalism: a clear choice for increased marketization, bringing with it a validation of private-sector methods and a denigration of public-sector service provision and government regulation, which is viewed as interference. These two movements - the information age and marketization - are related. As Schiller argues:

for definite reasons, political and economic elites assigned mounting strategic importance to information beginning around 1970. This was nothing less than an endeavor to renew the encompassing process of market expansion by generating around information a new and expansionary pole of growth for capitalism. (Schiller, 2007: xiv)

Like Webster (1995), Schiller (2007) criticizes postindustrial theorists for believing that we have transcended industrial society to enter a wholly new age, which did not allow for explanations based on systemic continuity (see also May, 2002). Rather, we have witnessed "what in fact has been a historically continuing process of commodification... The commodification of culture and information has been a continuing, if uneven and conflicted, process throughout the duration of capitalist development," which has greatly accelerated (Schiller, 2007: 35). Goulding once more highlights the tension here:

the challenge now is how well these two priorities can be married so that any further commodification of information and privatization of information channels do not encroach upon the citizen's fundamental right of access to knowledge, ideas and the products of creative thought and intellectual activity. (Goulding, 2001: 3)

Goulding (2001) again prophesies our current politics: citizens relying on private platforms, unregulated and concerned only with profit, for information, to make decisions of enormous magnitude (see, for example, the current discussions on nationalizing social media platforms, banning hate speech, banning political advertisements, and combatting dis- and misinformation online).

This diminishment of the public sphere is another characteristic of neoliberalism. According to Budd, neoliberalism

is the epitome of a political structure that eschews public good in favor of private interest... Perhaps the most insidious aspect of neoliberalism is its destruction of the public sphere and public space. In fact, there is no room for public in neoliberalism. (Budd, 2008: 173-174)

Moreover, neoliberalism erodes the very institutions intended to mitigate the impact of capitalist social contradictions, which of course encompasses the public library. Schiller details the destruction of the public realm by the actions of neoliberal policymakers 
through systematic preferment of corporate commercial interests, especially over earlier state programs for social welfare. Funding and service cutbacks were mandated for public-sector institutions such as schools and libraries, while privatization of not-for-profit service providers and widespread outsourcing bolstered corporate capital. (Schiller, 2007: 43-44)

He continues by listing some of the public institutions involved in information that have been affected by these changes: the US postal service, schools, universities, museums, archives, the Government Printing Office, libraries, and academic journals bought by publishing conglomerates. "These initiatives represent a consistent attempt to discredit, to attack as illegitimate, the very principle of non-proprietary information provision" (Schiller, 2007: 44).

Clarke (2004: 36-37), in his discussion of the neoliberal attempt to dissolve the public realm, speaks about a culture of managerialism as one of the culprits. He defines this as a pervasive business mindset that views the principles of management as applicable across all sectors - private, profit-motivated, public, not-for-profit, and voluntary-independent of what the nature of the service or business is. This view helps legitimize the hegemony of economic discourse. ${ }^{3}$ Clarke shows how this discourse, which has remade the public realm in the UK, aimed to depoliticize decision-making. Other commentators, in a similar vein, believe that we entered a time of consensus. The political philosopher Chantal Mouffe (2009)similarly castigated Tony Blair's Third Way for claiming to forge a path between left and right, and state and market, thereby eradicating conflict and contentious decision-making. Politicians attempted to appease all constituents by obfuscating real issues and opinions, and avoiding association with anything a voter could view pejoratively. In the UK, Margaret Thatcher's infamous denial of society - only individuals and families exist - mutated under David Cameron's Conservative-Liberal Democrat coalition government into the idea of the "Big Society," attempting to put ever more government functions back in the hands of the people (just as US conservatives aim for small government through service cuts). As Clarke (2004: 38) says: "The economic calculus is installed as the dominant decision-making calculus at supranational, national, local and organisational levels." Thirty years after Thatcher's government, market-based solutions are accepted by voters, who either no longer see or simply "tolerate the blurred lines between the private and public sectors" (Bagehot, 2010: 26). While trying to funnel government functions back to the people or the private sphere, the remaining services provided by government must be measured and evaluated just as in the private sphere, by adoption of private-sector methods, though they are not for profit. Even the UK Labour government "massively expanded the array and range of audit and inspection systems" (Clarke, 2004: 38).

Michael Sandel, the eminent American political philosopher, chose as his theme for the 2009 BBC Reith Lectures the moral limits of markets. He saw the 2008 financial crisis as an opportunity to finally rout the era of market triumphalism. He urged us to "rethink the role of markets in achieving the public good" and "the reach of markets into spheres of life where they don't belong." He argued that cost-benefit analysis done by economists aspires to scientific rigor and assigns monetary value to things, but that "many of the benefits of public policy involve values that can't be captured in monetary terms." Echoing Mouffe's critique of consensus politics referred to above,

market-mimicking governance is appealing because it seems to offer a way of making political choices without making hard and controversial moral choices. It seems to be non-judgmental . . . The non-judgmental impulse is also an anti-democratic impulse... The attempt to empty politics of moral controversy may seem to be a way of respecting our differences, but it is actually corrosive of democratic life. (Sandel, 2009)

These arguments regarding consensus also apply to the increasing discussion of library neutrality taking place. The rights that democratic citizenship bestows upon us come at the cost of responsibilities. But, for Sandel (2009), "notions of ease and convenience replace" the effort required by "democratic notions of inquiry, knowledge, and informed decisions." As Postman (1985) infamously wrote, we are amusing ourselves to death, turning the public into an audience of spectators and consumers as opposed to actively engaged participants. Similarly to Sandel, and at the same time, it appears that McMenemy (2009a: 400) was the first in the library and information science field to see an opportunity in neoliberalism's culpability in the financial crisis and the government bailout of private banks. He finds that there has been a lack of attention to the impact of neoliberalism on public libraries. According to McMenemy:

We have redrawn citizens as consumers, services provided for public benefit as items to be marketed, measured and in some cases sold. We have reduced the concept of public service to that of a transaction, measured in such superficial ways that the measurement 
itself becomes utterly meaningless. (McMenemy, 2009a: 403)

This ideology has affected libraries in two broad categories: evaluation and management or, more pejoratively, the infiltration of management by managerialism. Managerialism brings "explicit measures of performance and the imposition of private sector management practices... [it] has an ideological obsession with the benefits of quantitative measurement to determine service quality" (McMenemy, 2007a: 445-446). This makes sense in the private sector, where the goal is profit and therefore numbers, and sales, matter. But this approach does not convey much information about the quality of service in a library.

McMenemy (2007b: 275) objects to the domination of quantitative evaluation methods used for public libraries. The impact of public libraries on the community should not be measured solely or mostly by quantitative means. For instance, the focus on book-issue statistics leaves us with identical libraries full of populist fiction. Of course, these numbers give us information, but decisions cannot be made using them alone. In a section aptly headed "The tyranny of numbers," Usherwood (2007: 47), in the final book of his trilogy, says: "when libraries are part of a culture that places emphasis on profit and loss, and relies primarily on quantitative data, it changes the way in which libraries operate." This abundant quantitative data has influenced the way policymakers view assessment. Many institutions have faced increasing inspection regimes. In the UK, New Labour governments sustained the ethos of this measurement, initiated by the Conservatives before them.

Buschman (2003) critiques the lack of qualitative measurement within what he calls 'customer-driven librarianship'. This customer-driven focus recasts the library user as a customer, excluding the roles of citizen, researcher, and reader. Buschman (2003: 117) points out that this customer service trend is only a "tactical renaming of long-standing professional values," just as the long-established tradition of outreach is now called marketing and public relations. There is an unfortunate perception that this economic and business hue to language makes actions more legitimate. He reiterates the need for libraries to engage critically with this renaming, and with the bigger picture of public policy change:

Outside of a more comprehensive view of what is happening to public institutions, reacting to specifics (like library users as "customers") without recognizing the interconnections among such trends in librarianship and similar developments in other parts of the public sphere is futile. (Buschman, 2003: 118)

In the politically motivated trend of looking to the private sector to inform public-sector operations, there has been much writing on how libraries should emulate bookshops. This raises McMenemy's (2009b: 6) ire, as do the library and information science professionals who have embraced this model. Of course, the fundamentally different purposes of each-bookshops to sell books for profit by turning over stock and libraries to provide wide and free access to information by developing a collection-are not related, despite politicians' wishes.

Buschman also laments how bookstores are seen as libraries' successful competitors:

The bookstore/coffee-shop model represents a neartotal denigration of the value of intelligent selection and cataloguing of retrospective collections, ignoring the value of an investment in and maintenance of a collection (print, electronic, or otherwise) available over time. To equate the turnover and stock of a good bookstore and its inventory control system and salespeople with a library demonstrates a breathtakingly shallow understanding of what a library is and does. (Buschman, 2003: 114)

Elsewhere, Buschman (2005: 6) says: "Aping business rhetoric and models doesn't save libraries, it transforms them into something else." Usherwood (2007: 29) asks whether libraries are to be social institutions serving the public good through discerning stock selection and collection development or "quasi-retail outlets that simply seek to maximize their popularity by responding to populist demands?" If it is the latter, then how are they different from retail outlets and why should they be publicly funded? The library is not a bookshop; nor is it a substitute for the bookshop for disadvantaged people.

Usherwood agrees that

markets are at odds with the service ethic of the public library. Public libraries are not simply parts of the retail book trade but complex public service organizations that have to balance the needs of the individual with those of society as a whole. They should be managed and assessed accordingly. (Usherwood, 2007: 50)

Private companies are under no obligation to provide this balance (indeed, see discussions in several countries, including the USA and Ireland, regarding the post office's universal service obligation ensuring 
delivery to rural areas, which is being threatened by privatizing the service).

Buschman (2003: 121) makes it clear that he is not arguing that libraries should not respond to the desires of the community, but that this customer-driven librarianship relinquishes the library's public-sphere role, particularly in organizing social memory and rational discourse in a democracy. Unfortunately, Buschman (2003: 86) finds these ideas widespread in library administration, to the extent that "the literature of library management does not have a new public philosophy subtext. Rather, it is the text of that literature: there is no critical distance between economic/business management themes and those in librarianship."

Webster (1995: 49), a self-described critical friend of libraries, warns that professionals must examine the purpose of the library or "they meet the challenges of commercialisation unprepared, and incapable of doing more than adapting to a business agenda," where, we contend, they are bound to fail, as their role is not to sell for profit but to "provide an alternative to the many commercial institutions to be found in our society." The arenas in which one is a citizen are constantly dwindling. This is the role that the library should embrace to secure its future.

Turning the usual rhetoric on its head, Buschman asks:

What public purpose is served by public funding of a project imitative of the private sector? What right do we have to public funding to compete with businesses? Perhaps more importantly, does society need another model of media-dominated, entertainment-oriented consumerism in its public sphere? If we (libraries, schools, museums) do not hold out the possibility of alternatives and enact them, who will? (Buschman, 2003: 177)

\section{The documents}

Ex Libris, the 1986 Adam Smith Institute report with which we opened, foreshadows these changes. There, Mason (1986: 42) argues that: "There seems no good reason why the state should be expected to provide leisure and entertainment facilities of one kind free of charge to the user when it does not do so for others such as films or football." In other words, information is another commodity that the state should not be providing for free. The Institute's absolute freemarket loyalty is demonstrated in the following remark:

On grounds of principle, it would be preferable for the income of less well-off individuals to be increased so that they can choose the services they use on the same basis as the rest of society ... In practice, unfortunately, the principle of subsidized provision is now so strongly established...that it is unlikely to be readily abandoned. (Mason, 1986: 46)

\section{Furthermore:}

Providing libraries free has not been without other undesirable consequences. Some libraries have had to shut because their facilities were being abused by people with no intention to study but who used them simply as somewhere to congregate. In others, extra staff, including security guards, have had to be appointed to keep the problem under some sort of control. Vandalism and attacks on members of staff have had the inevitable effect of discouraging serious readers and students from using the reference and reading room facilities provided specifically for them. This growing incidence of violence and intimidation is encouraged by the fact that entry to libraries is free. The accommodation they provide attracts those with nothing else to do with their time, particularly rootless youngsters and people with alcohol problems. Once there, they cause problems. (Mason, 1986: 16)

This is an argument against all public space, and for the policing of private space. It insinuates that free public space encourages violence (thereby causing the state to expend more on security). Mason (1986) continues: "it is not unreasonable to suppose that an admission charge or membership fee would have acted as a significant deterrent to those whose interests apparently lie more in disturbance and destruction than in reading or study". The report is disdainful of disadvantaged people. It is characteristic of neoliberalism to challenge "conceptions of the public interest, striving to replace them by the rule of private interests, coordinated by markets" (Clarke, 2004: 31). This conservative focus on the individual and breaking down of social ties goes further and blames the individual for their woes:

The neo-liberal emphasis on the responsibility of the individual to take action to better their own living conditions was used to justify the withdrawal of state-led service provision and to blame the poor for their particular plight. Anyone who was not thriving in the market-led culture of this decade was assumed to be dysfunctional and wedded to a different and inferior set of values and behaviors. (Evans, 2004: 56)

Naturally, Mason (1986) does not appreciate the space separate to the market that the library provides. He suggests some revenue streams for libraries in advertising. However, 
were libraries, on the other hand to charge the economic cost of providing their services, the public would be able to decide for themselves whether or not the service was worth the money... It is only through charging economic prices and competing for customers in the market place that the real level of public demand for goods and services can be determined and a proper allocation of resources made. (Mason, 1986: 50)

Of course, users do pay for libraries - through taxation. But it seems for Mason that anything provided by the government prevents someone else from profiting from it, and is therefore problematic.

The report is thoroughly disparaging about the professional abilities of librarians throughout:

The range and standard of services and facilities provided would be determined by the consumer through his or her purchasing power, rather than by librarians and politicians... And breaking that monopoly would also remove the power, increasingly being abused, to dictate what people may or may not read. (Mason, 1986: 52)

What evidence is there of this abuse of power? For Mason, customer service is the only acceptable paradigm within which one's needs can be met. Why must one be a customer in order to get the service one wants? Why must employees view people as customers to give good service? Library patrons are citizens.

It does not seem hyperbolic to call this report caustic. These ideas might seem quaint in hindsight, except that 23 years later, we can trace the movement of these ideas from "the edge of lunacy" (as Pirie said in our introduction) into mainstream business policy documents. In June 2010, KPMG (a global auditing company and one of the big-four accountancy firmsi.e. not a right-wing think tank like the Adam Smith Institute) released Payment for success: How to shift power from Whitehall to public service customers (Downey et al., 2010), and this view reached its apogee. It is worth quoting at length:

The pattern of public service providers is still largely very traditional in structure and culture. It is still fundamentally based on professions demarcated in Georgian times... which are organized into Victorian institutions... and which are funded and governed in a 1940's settlement... This tri-fold structure can ... be a source of inflexibility and resistance to change, as well as becoming disconnected from the changing world in which it exists (given technology change, the greater affluence of citizens, etc.). The tri-fold has seen change in the last couple of decades through a mix of: managerialism (e.g. the New Public Management agenda and the creation of performance management and agencies); the use of IT [information technology] (e.g. through e- government); and some privatization (e.g. outright privatization in the utilities and the development of a mixed economy in social care and blue collar services). However, the general traditional pattern of public services remains distinctly intact. (Downey et al., 2010: 11)

Clearly, this report champions the exact changes we have outlined: managerialism, a focus on information and technology, and privatization. These changes are entirely positive in the view of the report's authors; indeed, they do not go far enough. It continues:

But devolution to local government is not the end of localism. A "local big state" is no more desirable than a "central big state". Local government should seek to devolve to the most local level possible and to encourage communities to take over services. One example would be libraries. Libraries face funding challenges - in that they are more discretionary than other services, usage has declined, the unit cost of lending a book can be more expensive than the wholesale price of a book and customers have new book and information media and services (e.g. Amazon, social networking sites, etc.). The level of community resistance to closing a library is usually disproportionate to the level of local usage, because communities believe that a local library belongs to them, not the council, and they believe in the future potential of the library to do great things. Devolution can allow new ideas to develop. For example - in North America libraries are often run by volunteers not paid council staff, whilst in the UK charity shops often have waiting lists of volunteers wanting to help them with book sales; much of the public space in a library is badly used storing infrequently used books; e-government has put libraries on line, but they still focus on a buildings based service; too many community groups are spending scarce resource on premises; where some councils have handed the library back to the community, they have often turned it into a much more vibrant community organisation and space. Giving councils total freedom on libraries could mean that they create huge social value from engaging a community in running its own library, backed up with some modern technology, whilst also saving large amounts of money on over-skilled paid staff, poor use of space and unnecessary stock. (Downey et al., 2010: 19)

This is a strong criticism of professional skills, physical buildings, and books that are less frequently checked out than others. The language is much more subtle, disguising the same argument.

Ex Libris and even Payment for success may be considered extreme views of right-wing, neoliberal, market-worshipping, business-oriented private organizations, but these organizations aim to influence government policy. We can see that these views have permeated into government policy in the UK's Department for Culture, Media and Sport's Empower, 
inform, enrich - the modernisation review of public libraries, released in December 2009. This statutory body, tasked with library advocacy, was due to issue a policy document at that time but issued a precursor consultation document. It opens with five challenges for libraries, each of which is questionable to a degree. $^{4}$

The five challenges are further delineated by a comprehensive list of 23 questions. The bulk of the document is essays, with case studies at the end, neither of which clearly answer the listed questions or tie to the aims. Furthermore, there is a contribution from the managing director of Starbucks UK and Ireland, which is surprising, and serves as an advertisement. "Can libraries follow suit?" she asks, after selling readers on the business model of Starbucks, which admittedly is her job (Department for Culture, 2009). But why should libraries follow suit with a retail space? What authority or expertise does a private retail manager have to advise on the future of libraries? This imposition of the bookshop model of libraries ignores their importance as a public space, not for profit, and free of charge to enter. Another concern is Minister Hodge's repeated desire to change the statutory obligation to provide libraries. She is "particularly interested in looking at some of the radical ideas on governance structures," and possibly reforming the legislative framework (Department for Culture, 2009: 9).

The following March, the review was released (Department for Culture, 2010). The five challenges remain and there are detailed aims and proposals of how to achieve them. Users are called "customers" throughout the document. It is disparaging toward the profession of librarianship, listing problems with professional education, calling for positions to be advertised outside the professional press, and strongly encouraging the use of volunteers (Department for Culture, 2010: 10). Twenty-three years later and here we see that Rusbridger's (1987) warning has been validated, and Pirie's prophecy has come true: the ideas espoused in Ex Libris had moved from "the edge of lunacy" to "the edge of policy" in the UK.

\section{Ireland: Irish government policy documents and the Irish context}

We have set the theoretical context in which change was taking place for libraries in Ireland and the UK in this period by discussing the rise of the informationsociety concept, expanding marketization and the commodifying of information, and the dissolution of public space in neoliberalism. Having detailed these circumstances, we turn to consider their applicability to the Irish context. In an effort to divine the extent to which these processes are evident in Irish local government and Irish libraries, we examined government reports from the period. The Irish government released its first policy document specifically about public libraries in 1998: Branching out: A new public library service (Department of the Environment, 1998). This was followed up with Branching out: Future directions (Department of the Environment, 2008). This article takes these two documents as bookends to analyze the impact of neoliberalism on Irish government policy for public libraries. Our end point is extended to 2011 - the general election which changed the governing party in reaction to the recession. Also relevant for our purposes are those documents detailing the implementation of service indicators as part of public-service reform. The increased quantitative measurement required by the public services is not detailed in the library-specific documents.

This article is envisaged as the initial part of a larger project to continue an analysis of the effects discussed here in the time period from the 2011 general election and the movement out of recession up to the present. The Local Government Management Agency published the Open Libraries pilot service 2014-2016 report in 2016, leading the way for a rollout of access to unstaffed libraries. The public library policy reports subsequent to 2008's Branching out: Future directions were Opportunities for all: Strategy for public libraries 2013-2017, released in 2013, and Our public libraries 2022: Inspiring, connecting and empowering communities, released in 2017 (future avenues for research could perhaps include a content analysis of all the reports, as Greene and McMenemy (2012) did in their cited chapter).

From 1987 until 2011, except for a short period (December 1994-June 1997), the center-right Fianna Fáil party governed Ireland, outright and in various coalitions. It faced decimation in the 2011 general election, attributed to the impact of the recession on Ireland (Collins, 2011; The Irish Times, 2011; McDonald, 2011). The writing may have been on the wall from the 2009 local and European elections, when the electorate meted out severe punishment to the ruling Fine Gael party, which had enacted many of the neoliberal policies outlined above (Kirby, 2010: 147; MacLaran and Kelly, 2014: 27). It should be noted that the situation in Ireland was slightly different to that of the UK and USA during this period in that this was a centrist-right-leaning government (rather than the center-left-leaning New Labour since 1997 and the Democrats in the 1990s, respectively). 
We begin by examining the implementation of increased quantitative measurement and evaluation of public service, as demanded by neoliberalism. Service indicators were introduced to Irish local government in 1994 with the public-service modernization program, the Strategic Management Initiative. The first report from this program was the publication Delivering better government in 1996 . It took several years to determine the indicators and get the initiative operating. The first national service-indicator report for local authorities was Delivering value for people (Department of the Environment, 2004). Serviceindicator reports have been issued every year since. As part of the Strategic Management Initiative, the Transforming public services report was published in 2008 (Department of the Taoiseach, 2008b). "Collectively, these reports have set the agenda for change in the Irish public and civil service" (McCarthy et al., 2011: 1). The Strategic Management Initiative was the first formal public-service reform agenda. Previous informal attempts over several decades had been unsuccessful (Browne, 1982: Murray, 2001: 4).

On the release of Delivering better government, The Irish Times (1996) stated: "As might be expected, the tone of the report is mild mannered." This comment, and the fact that it took so long to get the initiative off the ground, reflects some observations about Irish culture working against public-service reform (Murray, 2001: 5) The Irish Times continued: "but its vision of a user friendly, cost efficient public service - in which civil servants enjoy more autonomy and are more accountable to the public - is ambitious and laudable."

The trends we have discussed in this article are evident in these reports, though not to the same degree as in the UK (Kirby, 2010: 160). Certainly, performance indicators were adopted with vigor by government. They only applied to local government initially, but in the wake of OECD Public Management Reviews: Ireland 2008: Towards an Integrated Public Service (April 2008, pre-crash) and the government report Transforming public services (November 2008, immediately post-crash), the intention was to implement them across the public services. In contrast, local authorities in the UK have been statutorily obliged to publish these measurements since 1995. The UK regime is more rigorous and critiqued by some as "resource intensive" and "bureaucratic" (Department of the Environment, 2004: 15-19).

Delivering value for people (Department of the Environment, 2004) shows a healthy, measured attitude to service indicators. It states that while useful, the context of such data is important and should always be borne in mind. The service-indicator report for the following year (Local Government Management Services Board, 2006: 7) states: "The role of local authorities in libraries, arts, culture and recreation has increased considerably in recent years. The indicators do not capture the full extent of this involvement, a fact that has been acknowledged." Comparing the first service-indicator report of 2004 to that for 2008, it appears that there have been teething problems in implementation. There is a growing awareness of the limitations of such quantitative measurement (Local Government Management Services Board, 2009: 7). Moreover, "there is a danger in performance measurement in that 'what gets measured gets done' and this could skew the focus of local authorities away from key services which are not easily measured" (9). The authors of the report for 2008 positively cite Quinlivan and McCarthy, who argued that adopting the UK approach of using the indicators for many purposes runs the risk of "perverting and bureaucratizing the organization. Professionals and Managers alike can become prisoners of the system and the numbers game" (Quinlivan and McCarthy quoted in Local Government Management Services Board, 2009, 12). Even by 2009 , there is still a critical awareness of the issues with quantitative measurement in other jurisdictions and the implementation in Ireland.

In the 2004 report, only a small number of local authorities said that the service indicators were used to actually monitor performance against targets (Department of the Environment, 2004: 10). What is more, in the report for 2008, the Independent Assessment Panel, in its follow-up quality assurance exercise, confirmed that:

though the indicators are generally regarded as useful by the authorities and would, in their opinion, be compiled by them in any event, there was little evidence of their use as a management tool to set targets and to inform key decisions. This is a matter for concern given the not insignificant resources devoted to their compilation both on an ongoing basis and at the year end. (Local Government Management Services Board, 2009: 168)

This observation was also corroborated by a library head of service at the time, who said that such figures do not influence funding decisions (Pat McMahon, chief librarian for Galway City and County Libraries, personal communication, 2010). Here we see some possible resistance to the government's imposition of these measurement activities.

In a progressive move, the indicator report for 2008 changed from measuring the number of registered users to the number of library visits. Also, an indicator 
was added for the annual expenditure on stock per capita, in addition to the number of items issued per capita. Both of these new indicators are much fairer and give a more well-rounded picture of the service.

Yet everywhere we see the acceptance of the customer paradigm. The Delivering value for people report's first mention of "citizen" is on page 10 . Meanwhile, the report's second paragraph tells us that the government minister with responsibility convened a "Customer Service Group" to compile the report. "Citizen" is used 5 times and "customer" 16 times throughout (Department of the Environment, 2004).

The library-specific documents from this time period are Branching out: A new public library service (Department of the Environment, 1998), the first policy document for public libraries from an Irish government, and the follow-up Branching out: Future directions (Department of the Environment, 2008), which set policy for a five-year period. Branching out: A new public library service is a comprehensive report of over 100 pages. The foreword immediately ties libraries into the government policy goal of ensuring "that Ireland moves rapidly to embrace the opportunity of the Information Society so as to support economic and social progress as well as a more participative democracy" (Department of the Environment, 1998). The Irish government embraced and heavy relied on the information-society concept in government strategic planning documents (Kirby, 2010: 153; McCaffery 2007). In fact, it set up an Information Society Commission in 2001 (Roe, 2001; see McCaffery 2007 for earlier incarnations). It was quietly wound down only three years later (Kennedy, 2004). The report admits that libraries can be taken-for-granted institutions whose "value to the community is not often explicitly stated" (Department of the Environment, 1998: 16). Echoing the discussion of the concept in this article's literature review, the project team acknowledges that "the Information Society is much discussed, but little defined" (19) and continues by defining it in relation to library service provision. It is not only about technology but also about instigating social change.

Branching out: Future directions is a much shorter document at 68 pages, a large proportion of which is given to detailing the achievement of goals from the first report. Of note is that the word "customer" does not appear in the first report at all and is used twice in the second; the word "user" appears 31 and 8 times, respectively; and the word "librarian" appears 19 and 3 times, respectively. Despite the shorter length, this shows a change of terminology and focus in the intervening decade. Furthermore, the first report uses the phrase "information society" 16 times (one of which is in Information Society Commission), while the second report mentions it only 4 times, 3 of which refer to the Information Society Fund, therefore really only once. This demonstrates a clear waning of the importance of this concept as Internet access rose to criticalmass levels.

The second report addresses possible drawbacks to the imposition of quantitative measurement methods on local authorities by the central government:

In order to ensure that the library service attracts its potential audience, the Steering Group recommends that the value of existing measurement of usage be assessed and, in tandem, that an appropriate methodology of more widespread measurement of usage be developed. (Department of the Environment, 2008: 7)

This may have caused the change in indicators for usage in the service-indicator report for 2008 mentioned above. Finding this better method of measuring usage will "require investigation" and is a priority for the 2008-2012 period (51). The authors also advocate for libraries when they recognize that "statistics or key indicators cannot easily capture" "the level of innovation involved in implementation of Branching Out" (19).

Another of the listed priorities of the five-year plan foreshadows issues to arise in the library field in the coming years: "to develop, in the context of Towards 2016, innovative solutions to extending opening hours and maximising the availability of professional expertise of library staff for users and to consider the use of volunteers" (51). Opening hours were a strong focus of the 1998 report, and hours were greatly expanded in the following decade, as detailed in the 2008 report. Future research would cover the 2014 pilot and rollout of library access after hour, when unstaffed. This is a major labor issue. It is of great interest to see the question of hours here juxtaposed with maximizing access to staff expertise and also with volunteers, all in one priority bullet point. These become some of the biggest issues in the field in the subsequent years. In the UK, austerity policies brought the closure of nearly 800 libraries between 2010 and 2019 (Flood, 2019). The "Big Society" began a push for volunteerism, which rose enormously. A very large number of professional and paraprofessional positions were lost. It should be noted that 52 new libraries were built in Ireland in the decade between the reports, and the service-indicator reports reflected well on library service provision (Department of the Environment, 2008: foreword).

Branching out: Future directions may be compared to the Department for Culture, Media and 
Sport's (2010) Modernisation review of public libraries in that many of the same themes appear: a focus on technology, customer terminology, "innovative funding," public-private partnership, "delivery of many local authority services within a shared space," and marketing (Department of the Environment, 2008, 19). However, they are expressed less stridently in the Irish report. For example, in contrast to the Department for Culture, Media and Sport's (2010) "challenge" of demonstrating that libraries are still relevant, the aim in Branching out: Future directions is "to examine what would convince more people that public libraries are a relevant and useful part of their lives" (Department of the Environment, 2008: 45).

One of the stated marketing strategies is "to position libraries so that they are seen as community focal points and gateways for and to local authority, central government and cultural services" (Department of the Environment, 2008: 57). This new model of shared space suggests a higher position for the library, but it is acknowledged that co-location might dilute rather than enrich the service. In conclusion, between the 1998 and 2008 reports, we see a noticeable shift toward adopting more of the neoliberal terminology and policies discussed above, while at the same time there remains in Ireland a critical awareness of the importance and value of public libraries, and of the limitations of relying solely on quantitative measurements in the assessment of their value.

\section{Brief case study: a snapshot of the Galway service at the time}

What might the more appropriate methodology sought by the 2008 report's Steering Group look like? The word "qualitative" does not appear in the report, but it seems that consideration of qualitative measurements in the evaluation of libraries would be encouraged. In 2010, we interviewed the then chief librarian for Galway City and County Libraries, Mr Pat McMahon (Galway is the fourth-largest city in Ireland, a small city of approximately 100,000 people on the west coast). He was the chief librarian from 1995 to 2013, including the entire period covered by this article. He placed great value on qualitative evaluation and fought what he viewed as the onslaught of neoliberal rhetoric, ideology, and policy on libraries. This section provides a brief account of that interview, and McMahon's attempts to advocate for the library and emphasize the value left unmeasured by not looking qualitatively at libraries. He lamented increasing marketization, the influence of managerialism, business vocabulary, and the decline of the role of the public sphere and public space. Before Usherwood (2007) highlighted the dichotomy between equity and excellence in the third volume of his trilogy, the Galway Public Libraries blog said: "In our fiction collection we seek to combine the popular with the excellent. We are trying to develop a library collection that features books not readily available elsewhere" (Galway Public Libraries, 2006).

For its 2006 staff outing, the Library Council of Ireland chose to visit Galway City and County Library. As McMahon said, it was "not the best but the most interesting" (all quotes are from 2010, personal communication). Galway Library Service could be applauded for its lowest per capita spend at the time (of the 26 counties), but concomitantly it was near the bottom of the league table for per capita issue numbers. Membership was respectable, at halfway down the league table.

McMahon wondered what these figures actually tell us about Galway's library service and what impact the items borrowed have on people. To illustrate the deficiency of reliance on quantitative measures, McMahon mentioned an essay in Orhan Pamuk's Other Colors: Essays and a Story, in which Pamuk speaks about the pleasure of reading and, furthermore, the joy derived from simply carrying a great book as a "constant companion"; McMahon relayed that he had similarly carried Stendhal's The Red and the Black for three months during the summer holidays. This would be of no use to the library calculating its issue numbers. Rather, he believed, it testified to the unmeasurable value of the public library.

Also unmeasured is the value of the public library as a public space, a physical place to go free of direct cost. McMahon related a story of overhearing a conversation between two men as he left a branch library. One asked his friend where he was going. The other, a man to whom "life had not been kind," replied that he was going to the library to sit down for a while. McMahon thought this was "fantastic."

In January 2009, months after the financial collapse, the austerity budget implemented by the government slashed the book fund for Galway County Council by an enormous $80 \%$. McMahon embarked on a campaign for the library, in which, he said, not a week went by when he did not bring evidence of the value of libraries to the attention of the relevant authorities: the county manager, the finance officer, and the mayor, for example. One effect of the recession had been the increase in circulation rates by $16 \%$ from 2007 to 2009 . The budget was significantly increased in 2010, though not restored.

In the course of that campaign, he uploaded a video to YouTube in which he said: "In these times which 
are characterized by the total domination of modern technology, surely it is necessary and urgent to reconsider language, the role of books and reading, and the role of public libraries." Citing the Greek writer Vassilis Vassilikos' idea of the non-liberating dream, he said: "this is the dream television tries to sell us... The non-liberating dream is everywhere today. Everyone is selling it to you every minute of your waking life". The opposite - the liberating dreamis available at the public library because it is a space outside the market. Libraries have a value "regardless of popularity and profitability." (Galway Libraries, 2009) Libraries must not be market-driven.

In a letter to an editor regarding the government's introduction of service indicators, he said: "If the service given by a public library authority is going to be measured by such a crude device as the number of books issued, then it is going to have a detrimental effect on the quality of service." In conversation, McMahon quoted the French poet Jean-François Manier: "The book is such an inordinate life stake that it requires criteria of value other than the rate of its turnover."

In 2011, Fianna Fáil was voted out. It was the first general election since the start of the recession in 2008. There is a total of 166 seats in the Irish parliament. The party went from 71 to 20 , losing 51 . Fine Gael, the other major party (these two parties have traded power since independence), went from 51 to 76, gaining 25 (Wikipedia, n.d.). This massive loss of seats, unprecedented in Irish history, reflected the Irish people's dissent regarding the policies enacted by Fianna Fáil and the party's response to the global recession, much of it textbook neoliberalism.

Another important event to be noted during this period was the abolition of An Chomhairle Leabharlanna (the Library Council of Ireland). It was the only statutory body for libraries in Ireland, created in 1947 under the aegis of the Department of the Environment and Local Government. When the Fine Gael party swept to power with a resounding election success in 2011, on the back of the recession, it announced a culling of quangos (quasi non-governmental organizations) as a cost-saving measure (Phelan, 2015). An Chomhairle Leabharlanna was dissolved in 2012. The responsibilities of this body (and its staff) were subsumed within the Local Government Management Agency and renamed Libraries Development. There was little to no response from the library community in Ireland. The second part of this project would review the effects of the dissolution of An Chomhairle Leabharlanna and the effectiveness of the Local Government Management Agency in taking up its mantle, as well as reviewing the policy documents issued by the new Fine Gael government from 2011 to the present.

\section{Conclusion}

We have outlined changes wrought by neoliberalism on public services, and public libraries in particular, in the first years of this century. As Buschman (2003: 170) says, these changes can appear to have occurred "naturally" without much debate about how we would like our public cultural institutions to operate, but are in fact direct results of systematic policy changes due to neoliberal thinking. Indeed, we have reached a point where it can appear absurd, or at least meaningless, to defend libraries using the discourse of democracy and civil society (Buschman, 2003: 101; Chapman and Webster, 2006: 647). Buschman (2003) finds that management rhetoric (managerialism) is eroding the public sphere and managing away the institution of the library as well. McMenemy (2007b) and Usherwood (2007) also express this idea that the very methods which have been embraced by the library and information science field are allowing for the argument to be made against the library. The public library should stop "attempting to justify itself through meaningless formulas that both potentially devalue it, and can be used as weapons against its very existence" (McMenemy 2007b: 276). When these changes of neoliberalism initially came about, Buschman (2003: 7) felt that the defense by librarianship was a "rehearsed litany that constituted "little more than the ritual deployment of slogans"". Indeed, Budd "unpacks the multiple and often contradictory meanings of democracy and information society to show that librarians should be more aware of how these obfuscations promote certain interests over others" (Rowland, 2009: 169). Throughout this article, the importance of language and the effect of neoliberalism on professional language have been evident. There is scope for further research into Mouffe's theory of articulation here: "If abstractions like 'democracy' and 'liberty' are identified with existing institutions, this will present a barrier to the diffusion of alternative images of society" (Femia, 1987: 44).

Detractors may attempt to discredit these arguments by suggesting that they are ideological or wishful. In response, Buschman (2003) is not "suggesting that librarianship will lead the West out of the wilderness of a soulless capitalism, dominated by media spectacle." Nor is he advocating a vision of an imperial librarianship with an unassailable "higher purpose." He is simply saying that the role of libraries in the public sphere is very important; there is "a need 
to provide alternatives and alternative spaces in a culture dominated by information capitalism and media image and spectacle." Faced with this "ethic of the private and the consumer" in so many arenas of life, libraries provide an alternative (180). "No other types of institutions will be able to do so; certainly none have a compelling reason to" (178). "Put at its most basic, if these institutions should not be thought of primarily in economic terms, then they must be situated in the public sphere" (37).

Necessary to the public-sphere idea is the provision of public space. Alstad and Curry (2003) make the same point as Sandel (2009) that the corporate encroachment on public and cultural space prevents different types of people coming into contact. This is detrimental to democracy and causes polarization. This is another facet to the library's role as an alternative to the market. We should not rely on the private sector to provide ostensibly public spaces because the use of private space is not a right:

The requirement that these spaces be both profitable and safe has led to a demand for total management and controlled behaviour, which precludes political activity and undermines the public dimension of the space (Madanipour 1999). It also alienates and discourages a sense of belonging and community for large segments of society. An increasing preference for privacy and security "diminishes social interaction and diversity, if only because strangers of differing ages, classes, ethnicities, genders and religions have less opportunity to mingle in the same physical space" (Leckie and Hopkins 2002).

The loss of civic space and the resultant lack of unmediated social interaction is damaging to a democracy ... These are critical issues in an age of rapid changes in electronic communication, powerful pressures towards consumer individualism, and increasing disparities in wealth and access to information. (Alstad and Curry, 2003)

All three issues referred to in that last sentence have intensified in the intervening years. Furthermore, for Mouffe (1993: 6), if the political is extinguished and moral values are relegated to the private sphere, then conflict is sublimated and manifests elsewhere, leading to problems such as the rise of the extreme right and fundamentalism, symptoms of a "confrontation between non-negotiable moral values."

Buschman (2003: 101) finds library and information science's engagement with democratic theory inadequate. His hope is to encourage the field to use thinkers who can bridge the gap between theory and practice, and recognize that democracy is not a thing to be attained, a static state which we will reach, but rather a continuing process. To Buschman's list we would add Mouffe. Budd (2008: 164-165) mentions Mouffe's political agonism briefly in his discussion of democracy. Mouffe critiques the dominant political philosophy of Rawls and Habermas for attempting to eradicate conflict and undecidability from the public sphere. Like Buschman, central to Mouffe's approach

is the awareness that a pluralist democracy contains a paradox, since the very moment of its realization would see its disintegration. It should be conceived as a good that only exists as good so long as it cannot be reached. Such a democracy will therefore always be a democracy "to come"... which confronts the consequences of acknowledging the permanence of conflict and antagonism. (Mouffe, 1993: 8)

Mouffe rebukes the progressive politics represented by Blair's New Labour and theorized by Anthony Giddens in Beyond Left and Right and The Third Way. She abhors their transcendence of the traditional leftright dichotomy, a 'win-win politics without adversary' that pretends to eliminate power relations in a situation of consent.

Foucault told us that "the time of men does not have the form of an evolution, but precisely that of a history" (Smart, 1986: 171). Indeed, Foucault's intention in his genealogical analyses was to "bring it about that [we] 'no longer know what to do,' so that the acts, gestures, discourses which up until then had seemed to go without saying became problematic," just as Buschman (2003: 181) cites Maxine Greene, reminding us that things can always be other than they are. In this vein, this article intended to raise questions about the current paradigm in which public library service is provided, by evincing it from government reports and literature about public provision. The extent of neoliberalism-defined by marketization, information capitalism, erosion of the public sphere, quantitative evaluation of public service, privatesector methods expanded to public service, and changes in work practices - has been explored, and we have examined the degree to which it manifests in library provision in Ireland.

Considering the changes wrought by neoliberal policies, we urge a development of critical awareness in library and information science education and the field. The role of public libraries juxtaposed with the changing conceptions of democracy, public provision, and information must continue to be examined. This research is of practical significance in calling for librarians to fully engage with these ideas, recognize obfuscating critiques, and prepare a defense. It is of academic significance in that there is no literature on 
neoliberalism and Irish libraries, or analysis of the policy documents issued using this lens. The thinkers whose views we have delineated here provide strong arguments for protecting the continuing role of the library as an alternative space in the public sphere when much else is market-driven. They also provide an impetus for information professionals to see it as their duty to be informed. Indeed, it is our ethical responsibility to engage in self-examination, form an opinion, and take a thoughtful stance so that we are the drivers of change in the future.

\section{Declaration of conflicting interests}

The author declared no potential conflicts of interest with respect to the research, authorship, and/or publication of this article.

\section{Funding}

Support for this project was provided by a PSC-CUNY award, jointly funded by the Professional Staff Congress and the City University of New York.

\section{ORCID iD}

Maureen Garvey (D) https://orcid.org/0000-0001-7950-3 791

\section{Notes}

1. His critique foreshadows later discussion of the use of quantitative measures by management in business and local government.

2. Similarly, Webster (1995: 220) identified 400 conceptions of information in the literature: "the 'bundling' of all these concepts under one term both homogenizes extraordinarily different activities and spheres... and collapses the meaning of the word itself." The political philosophers Laclau and Mouffe (1985) outlined this realignment of meaning for many concepts - most notably democracy - in their theory of articulation. There are avenues for future research here.

3. Related to this is the devaluing of social sciences and humanities in academia, where the qualitative evaluation needed to counter the economistic quantitative focus takes place.

4. The first challenge is to demonstrate that libraries are still relevant and vital. This, of course, accepts with seriousness that they may not be. The second challenge is to increase use, bringing to mind the debate between equity and excellence considered by Usherwood (2007), and the difference between equality of access and equality of use. The third challenge refers to the immediacy of access needed in our " $24 / 7$ culture," which raises the issue of speed as a virtue at the possible cost of quality and accuracy. The fourth challenge is about extending the opportunities presented by digitization to all libraries, bringing with it debates about the centrality of information technology to our information lives, questions of quality, and effort in finding sources and discrimination between sources/evaluation of those sources, and funding. The final challenge reminds us that we must face all these whilst under economic pressure and with limited resources.

\section{References}

Alstad C and Curry A (2003) Public space, public discourse and public libraries. LIBRES 13(1). Available at: https:// www.libres-ejournal.info/916/

Bagehot (2010) Not yet grim up north. The Economist, 14 August, https://www.economist.com/britain/2010/08/ 12/not-yet-grim-up.

Black A (2006) Introduction: The public library in concept and reality. In: Black A and Hoare P (eds) The Cambridge History of Libraries in Britain and Ireland. Cambridge: Cambridge University Press, 19-23.

Black A and Hoare P (2006) Libraries and the modern world. In: A Black and P Hoare (eds) The Cambridge History of Libraries in Britain and Ireland. Cambridge: Cambridge University Press, 7-18.

Browne V (1982) The uncivil service: The obstruction of reform. Magill. Available at: https://magill.ie/archive/ uncivil-civil-servants-obstruction-reform

Budd J (2008) Self-Examination: The Present and Future of Librarianship. Westport, CT: Libraries Unlimited.

Buschman J (2003) Dismantling the Public Sphere: Situating and Sustaining Librarianship in the Age of the New Public Philosophy. Westport, CT: Libraries Unlimited.

Buschman J (2005) On Libraries and the public sphere. Library Philosophy and Practice 7(2): 1-8.

Chapman L and Webster F (2006) Libraries and librarians in the information age. In: Black A and Hoare P (eds) The Cambridge History of Libraries in Britain and Ireland. Cambridge: Cambridge University Press, 639-653.

Clarke J (2004) Dissolving the public realm? The logics and limits of neo-liberalism. Journal of Social Policy 33(1): $27-48$.

Collins S (2011) FF will never recover former position. The Irish Times, 28 February. Available at: https:/www. irishtimes.com/opinion/ff-will-never-recover-formerposition-1.584494

Department for Culture, Media and Sport (2009) Empower, inform, enrich - the modernisation review of public libraries: A consultation document. London: Stationery Office.

Department for Culture, Media and Sport (2010) The modernisation review of public libraries: A policy statement. London: Stationery Office.

Department of the Environment, Heritage and Local Government (1998) Branching out: A new public library service. Dublin: Stationery Office.

Department of the Environment, Heritage and Local Government (2004) Delivering value for people: Service indicators in local authorities. Dublin: Local Government Management Services Board. 
Department of the Environment, Heritage and Local Government (2008) Branching out: Future directions. Dublin: Stationery Office.

Department of the Environment, Community and Local Government (2013) Opportunities for all: The public library as catalyst for economic, social and cultural development. Dublin: Stationary Office.

Department of Rural and Community Development (2018) Our public libraries 2022: Inspiring, connecting and empowering communities. Dublin: Stationery Office.

Department of the Taoiseach (2008a) Building Ireland's smart economy: A framework for sustainable economic renewal. Dublin: Stationery Office.

Department of the Taoiseach (2008b) Transforming public services: Report of the Task Force on the Public Service. Dublin: Stationery Office.

Downey A, Kirby P and Sherlock N (2010) Payment for success: How to shift power from Whitehall to public service customers. London: KPMG.

Evans K (2004) Maintaining Community in the Information Age: The Importance of Trust, Place and Situated Knowledge. Basingstoke: Palgrave Macmillan.

Femia JV (1987) Gramsci's Political Thought: Hegemony, Consciousness and the Revolutionary Process. Oxford: Clarendon Press.

Flood A (2019) Britain has closed almost 800 libraries since 2010, figures show. The Guardian, 6 December. Available at: https://www.theguardian.com/books/ 2019/dec/06/britain-has-closed-almost-800-librariessince-2010-figures-show

Fukuyama F (1992) The End of History and the Last Man. New York: Free Press.

Galway Libraries (2009) Pat McMahon, Galway librarian, on the public library service. YouTube, 14 April. Available at: https://www.youtube.com/watch?v $=\mathrm{sS}$ $\mathrm{uCO} 2 \mathrm{ra3}$ o\&list $=$ PL53664F5C3FAA4FFA\&index $=45$

Galway Public Libraries (2006) Literature defeats time. In: Galway Public Libraries blog. Available at: http://gal waylibrary.blogspot.com/2006/06/literature-defeatstime_29.html

Greene M and McMenemy D (2012) The emergence and impact of neoliberal ideology on UK public library policy, 1997-2010. In: Spink A and Heinstrom J (eds) Library and Information Science Trends and Research: Europe Volume 6. Emerald Group Publishing Limited, 13-41. http://dx. doi.org/10.1108/S1876-0562(2012)0000006005

Goulding A (2001) Information: Commodity or social good. Journal of Librarianship and Information Science 33(1): $1-4$.

Harvey D (2005) A Brief History of Neoliberalism. Oxford: Oxford University Press.

The Irish Times (1996) Reforming the civil service. 3 May. Available at: https://www.irishtimes.com/opinion/ reforming-the-civil-service-1.45664

The Irish Times (2011) Election 2016: Results for 2011. Available at: https://www.irishtimes.com/election2016/results-2011
Kennedy J (2004) ISC to be discontinued. Silicon Republic, 22 November. Available at: https:/www.siliconrepub lic.com/enterprise/isc-to-be-discontinued

Kirby P (2010) Market: Neo-liberalism Irish-style. In: Celtic Tiger in Collapse: Explaining the Weakness of the Irish Model. London: Palgrave Macmillan, 146-164.

Laclau E and Mouffe C (1995) Hegemony and socialist strategy: Towards a radical democratic politics. London: Verso.

Local Government Management Agency (2016) Open Libraries Pilot Service 2014-2016, Report of Libraries Development, June 2016.

Local Government Management Services Board (2006) Service indicators in local authorities 2005. Dublin: LGMSB. Available at https://www.lgma.ie/en/publica tions/performance-indicators/service-indicators-inlocal-authorities-2005.pdf

Local Government Management Services Board (2009) Service indicators in local authorities 2008. Dublin: LGMSB. Available at https://www.lgma.ie/en/publica tions/performance-indicators/service-indicators-inlocal-authorities-2008.pdf

McCaffery C (2007) Irish information society policy. Les politiques territoriales des TIC en Europe 21(1-2): 209-240.

McCarthy A, Grady G and Dooley G (2011) Leadership in the Irish civil service: A $360^{\circ}$ review of senior management capability. Galway: Centre for Innovation and Structural Change, National University of Ireland Galway. Available at: http://www.nuigalway.ie/cisc/docu ments/leadership_in_the_irish_civil_service.pdf

McDonald H (2011) Fianna Fáil trounced as Fine Gael and Labour set to form coalition. The Guardian, 26 February. Available at: https://www.theguardian.com/world/ 2011/feb/26/fianna-fail-irish-general-election

MacLaran A and Kelly S (2014) Irish neoliberalism and neoliberal urban policy. In: MacLaran A and Kelly S (eds) Neoliberal Urban Policy and the Transformation of the City. London: Palgrave Macmillan, 20-36.

McMenemy D (2007a) Managerialism: A threat to professional librarianship? Library Review 56(6): 445-449.

McMenemy D (2007b) What is the true value of a public library? Library Review 56(4): 273-277.

McMenemy D (2009a) Rise and demise of neoliberalism: Time to reassess the impact on public libraries. Library Review 58(6): 400-404.

McMenemy D (2009b) Telling a true story or making it up: Discourse on the effectiveness of the bookshop model for public libraries. Library Review 58(1): 5-9.

Mason D (1986) Ex Libris. London: Adam Smith Institute.

May C (2002) The Information Society: A Sceptical View. Cambridge: Polity Press.

Monbiot G (2016) Neoliberalism - the ideology at the root of all our problems. The Guardian, 15 April. Available at: https://www.theguardian.com/books/2016/apr/15/ neoliberalism-ideology-problem-george-monbiot

Moran C and Quinn P (2006) The Irish library scene. In: Black A and Hoare P (eds) The Cambridge History of 
Libraries in Britain and Ireland. Cambridge: Cambridge University Press, 253-265.

Mouffe C (1993) The Return of the Political. London: Verso.

Mouffe C (2009) The Democratic Paradox. London: Verso.

Murray J (2001) Reflections on the SMI. Working paper for The Policy Institute, Trinity College Dublin. November. Available at: https://www.tcd.ie/policy-institute/assets/ pdf/PIWP01_John\%20Murray.pdf

OECD (2008) OECD Public Management Reviews: Ireland 2008: Towards an Integrated Public Service. Paris: OECD Publishing, https://doi.org/10.1787/9789264043 268-en.

Phelan S (2015) Bonfire of the quangos burns 181 bodiesbut just $€ 15 \mathrm{~m}$ in savings. The Independent, 2 February. Available at: https://www.independent.ie/irish-news/ bonfire-of-the-quangos-burns-181-bodies-but-just15m-in-savings-30955801.html

Postman N (1985) Amusing Ourselves to Death: Public Discourse in the Age of Showbusiness. London: Methuen.

Robins K and Webster F (1999) Times of Technoculture: Information, Communication, and the Technological Order. London: Routledge.

Roe D (2001) Ahern unveils Information Society Commission. The Irish Times, 27 November. Available at: https:/www.irishtimes.com/news/ahern-unveils-infor mation-society-commission- 1.405304

Rowland F (2009) Review of Self-Examination: The Present and Future of Librarianship by John Budd. Portal: Libraries and the Academy 9(1): 169-170.
Rusbridger A (1987) Adam Smith Institute's sense and nonsense. The Guardian, 22 December. Available at: http://www.guardian.co.uk/politics/1987/dec/22/uk.past

Sandel M (2009) A new politics of the common good. The Reith Lectures. Available at: http://www.bbc.co.uk/pro grammes/b00lb6bt

Schiller D (2007) How to Think about Information. Urbana: University of Illinois Press.

Smart B (1986) The politics of truth and the problem of hegemony. In: Hoy DC (ed.) Foucault: A Critical Reader. Oxford: Blackwell, 157-174.

Usherwood B (2007) Equity and Excellence in the Public Library: Why Ignorance Is Not Our Heritage. Aldershot: Ashgate.

Webster F (1995) Theories of the Information Society. London: Routledge.

Wikipedia (n.d.) 2011 Irish general election. Available at: https://en.wikipedia.org/wiki/2011_Irish_general_elec tion (accessed 9 July 2020).

\section{Author biography}

Maureen Garvey is an instruction librarian and Coordinator of Reference at the College of Staten Island, CUNY. After completing library school in London, she interned at the Library Council of Ireland and the Royal Irish Academy. She has worked at several academic libraries in New York and New Jersey. Her first Master's degree is in Cultural and Ethical Studies. She has published on Cuban library services. 